\title{
ANTIVIRAL AND IMMUNE STIMULANT ACTIVITIES OF GLYCYRRHIZIN AGAINST DUCK HEPATITIS VIRUS
}

\author{
Hamdy Soufy ${ }^{1}$, Safaa Yassein ${ }^{2}$, Alaa R. Ahmed ${ }^{2}$, Mohamed H. Khodier ${ }^{3}$, Mohamed A. Kutkat ${ }^{4}$, \\ Soad M. Nasr* ${ }^{1}$ and Faten A. Okda ${ }^{1}$ \\ ${ }^{1}$ Department of Parasitology and Animal Diseases, National Research Center, El-Behouse \\ Street,Dokki, Post Box, 12622, Giza, Egypt. \\ ${ }^{2}$ Department of Clinical Pathology, Faculty of Veterinary Medicine, Cairo University, Giza, Egypt. \\ ${ }^{3}$ Department of Virology, Veterinary Serum and Vaccine Research Institute, Cairo, Egypt. \\ ${ }^{4}$ Department of Poultry Diseases, National Research Center, El-Behouse Street,Dokki, Post Box, \\ 12622, Giza, Egypt. \\ *E-mail: soadnasr@yahoo.com
}

\begin{abstract}
This study was conducted to investigate the effect of glycyrrhizin as an immune stimulant against duck hepatitis virus (DHV). In vitro study was carried out to determine cytotoxic and antiviral effects of glycyrrhizin in VERO cells. In vivo study was performed on 40 one-day-old White Pekin ducklings. -and the birds weres divided into 4 groups: control, glycyrrhizin treated, vaccinated with live attenuated DHV vaccine and glycyrrhizin treated and vaccinated; to investigate the changes in immunity and challenge test. Blood samples were collected from each duckling for evaluation of cellular and humeral immunity. The in vitro results revealed that glycyrrhizin had antiviral and no toxic effects till $10^{6}$ dilutions. Higher antibody titer was observed from the $5^{\text {th }}$ week till the end of experiment in glycyrrhizin and vaccinated group. Treatment with glycyrrhizin alone or with DHV vaccine demonstrated a pronounced lymphocytic proliferation response after 4 days postinoculation till the end of experiment, while vaccinated group revealed a pronounced proliferation response after 24 days post-inoculation. Treatment with glycyrrhizin alone or combination with DHV vaccine revealed good immune stimulant and antiviral effect against DHV.
\end{abstract}

Keywords: Glycyrrhizin, immune stimulant, Duck hepatitis virus

\section{Introduction}

The triterpene glycoside glycyrrhizin is the main active compound in licorice or liqurice (Glycyrrhiza glabra Linné) belonging to the family of Leguminosae). It undergoes an enterohepatic cycling, during which it is metabolized by $\beta$ glucuronidase of commensal bacteria to glycyrrhetinic acid. Glycyrrhizin (GL) is an aqueous extract of licorice root, used as a sweetening and flavoring agent due to its extreme sweetness (Zhang and Ye, 2009). It consists of one molecule of glycyrrhetinic acid and two molecules of glucuronic acid (Mao et al., 2005). It can effectively protect liver against fulminant hepatic failure induced by galactosamine and lipopolysaccharide (Yang et al., 2007).

Glycyrrhetinic acid has a corticosteroid-like structure, and has been shown to possess several beneficial pharmacological activities, such as anti-inflammatory activity (Houssen et al, 2010; Shi et al., 2010), immunomodulating (Chung et al., 2001), and enhanced the production of antibodies through the production of interleukin 1, 2 and 12 (Zhang et al., 1992, 1993; Dai et al., 2001), induction of gamma interferon, a natural anti-viral (production by T-cells), an endogenous lymphokine known to inhibit viral replication. This leads to significant antiviral activity (Hattori et al., 1983), antioxidative activities (Nagai et al., 1992) and hepatoprotective properties (Maatooq et al., 2010).

Duck hepatitis virus (DVH) is one of the most economic important diseases to all duck growing farms because of its high potential mortality if the infection is not controlled (Saif et al., 2003). It is an acute highly fatal rapidly spreading viral infection of young ducklings. It was first recorded in New York and Taiwan. The morbidity is $100 \%$ and the mortality may reach $95-100 \%$ in the first week of age (Mahdy, 2005). The present work was designed to investigate the effect of glycyrrhizin (active principle of licorice) as an immune stimulant and antiviral agent on ducklings experimentally infected and/or vaccinated with duck hepatitis virus in vitro and in vivo studies.

\section{Materials and Methods}

Purification and identification of glycyrrhizin from licorice plant

Two kg of licorice root (Glycyrrhiza glabra L.) was obtained from Haraz, Abdeen, Cairo, Egypt for isolation of Glycyrrhizin (GL). Purification of glycyrrhizin from licorice was performed according to Bentley and Trimen (1880). The extracted and purified substances were identified using thin layer chromatography (TLC) according to Cui et al. (2005).

The administered glycyrrhizin (purified glycyrrhizin $0.2 \%+$ cysteine $0.1 \%+$ glycine $2 \%$ dissolved in physiological saline) were inoculated 3 times weekly for 4 weeks (Mori et al., 1990). Cysteine and glycine were added to avoid side effect of glycyrrhizin by increasing glutathione synthesis and prevent sodium and water retention effect. 
Publisher: African Networks on Ethnomedicines

Web page: /http://journals.sfu.ca/africanem/index.php/ajtcam/indexl

http://dx.doi.org/10.4314/ajtcam.v9i3.14

\section{Virus preparation and titration in cell cultures}

Virulant Duck hepatitis virus (DHV) strain and live attenuated duck hepatitis vaccine were kindly supplied from Vet Serum and Vaccine Research Institute, Abassia, Cairo, It was used for vaccination of ducklings and preparation of hyper immune serum, whereas Vero Cell culture had a titer of $10^{6}$ tissue culture infective dose $50\left(\mathrm{TCID}_{50} / \mathrm{ml}\right)$, and used for serum neutralization test (SNT) for estimation of DHV antibodies in the serum of treated and vaccinated ducklings. Each passage of DHV was titrated in the corresponding cell culture using the microtiter plate according to Florence et al. (1992). The end point was determined and the virus titer was calculated according to Reed and Muench (1938).

\section{In vitro studies}

Cytotoxic effects of glycyrrhizin, glycin, cysteine and mixture of glycyrrhizin, cysteine and glycine was performed according to Khodier and Sahar (2006). All samples were dissolved in physiological saline and sterilized by filtration using $0.22 \mu \mathrm{m}$ milipore filter. The cellular cytotoxicity assay was carried out using $0.1 \mathrm{ml}$ cell suspension containing 10,000 cells seeded in each well of 96-well microtiter plate. Fresh medium containing 10 fold dilutions of the tested samples was added after $24 \mathrm{hr}$ of seeding. Control cells were incubated without test sample. The microtiter plate was incubated at $37^{\circ} \mathrm{C}$ with $5 \%$ $\mathrm{Co}_{2}$ for $72 \mathrm{hr}$. The morphology of the cells was inspected daily for microscopically detectable alterations.

\section{Determination of the antiviral activity of glycyrrhizin}

Confluent monolayer of Vero cells (African Green Monkey Kidney Cell Line) in 96-well plates were inoculated with $25 \mu \mathrm{L}$ of DHV (100 $\left.\mathrm{TCID}_{50}\right)$; median tissue culture infectious dose; then overlaid with $25 \mu \mathrm{L}$ of each non-toxic concentration of the tested samples. The antiviral property was determined using the cytopathic effect (CPE) inhibitory assay (HU and Hsiung, 1989) and the virus yield reduction assay (Cinatl et al., 1997). The anti-DHV activity was determined by inhibition of CPE compared with untreated infected cells (Control).

\section{In vivo studies}

Forty one-day-old White Pekin domestic ducklings used in this study were obtained from a private non vaccinated parent flock. Ducklings were housed under hygienic measures in separate isolators receiving a balanced growing broiler ration, containing protein $21 \%$, fats $3.6 \%$ and fibers $3.4 \%$ according to NRC (1994). They were equally divided into 4 groups (10 birds/group) where the first group was kept as negative control. The second group was inoculated I/P (3 times/weekly/for four weeks) with $10 \mathrm{mg}$ of glycyrrhizin $/ \mathrm{kg}$ b.wt. The third group was inoculated $\mathrm{I} / \mathrm{M}$ with $0.5 \mathrm{ml}$ of live attenuated DHV vaccine. The fourth group was inoculated with both $10 \mathrm{mg}$ of glycyrrhizin $/ \mathrm{kg}$ b.wt. and DHV vaccine $(0.5 \mathrm{ml})$. Two blood samples were collected from each duckling by jugular vein puncture before treatment for screening the presence of maternal antibodies for DHV then 4 days after vaccination then weekly for 7 weeks. One sample was anti-coagulated using heparin for evaluation of cellular immunity at the $4^{\text {th }}, 14^{\text {th }}$, and $24^{\text {th }}$ day of treatment. The other sample was placed in a plain centrifuge tube for serum separation and neutralization Test.

\section{Evaluation of cellular immune response}

Lymphocyte proliferation assay (LPA) was measured using ELISA BrdU (Colorimetric) kit according to Perros and Weightman (1991). The kit was made by Roche Diagnostics, Penzberg, Germany.

\section{Evaluation of the humeral immune response}

The DHV antibodies in duckling sera titers were calculated as the reciprocal of the final serum dilution which neutralized and inhibited the CPE of 100-200 $\mathrm{TCID}_{50} / \mathrm{ml}$ of the used virus (Singh et al., 1967). SNT was applied on the sera obtained from five randomly selected ducklings from each vaccinated and control group.

\section{Challenge test}

The ducklings of each group at the $25^{\text {th }}$ day old were challenged with $0.5 \mathrm{ml}$ virulent DHV containing $10^{7} \mathrm{TCID}_{50}$ per duckling intra muscular (I/M). The experiment was done according to guidelines for animal experimentations and approved by the institutional animal care and use Committee National Research Center, Animal care Unite, Dokki, Giza, Egypt.

\section{Statistical analysis}

Results are expressed as the mean \pm SD. Differences between control and treated groups were tested for significance using a one-way analysis of variance followed by least significant difference (LSD). Differences were considered significant at $p<0.05$ level (Snedecor and Cochran, 1982) using SPSS version 10 computer programme. 
Publisher: African Networks on Ethnomedicines

Web page: /http://journals.sfu.ca/africanem/index.php/ajtcam/indexl

http://dx.doi.org/10.4314/ajtcam.v9i3.14

\section{Results}

Purification and identification of GL

The isolated glycyrrhizin (A) had the same band of standard glycyrrhizin (B) on silica gel at retention factor (RF) = 0.74 of isolated GL to RF $=0.76$ of the standard GL (Figure 1)

\section{The cytotoxic and antiviral effect}

Inoculation of different dilutions (up to $10^{6}$ ) of isolated glycyrrhizin, glycine, cysteine, and mixture of all (glycyrrhizin, glycine and cysteine) did not show any cytotoxic effect in the inoculated Vero cells. Moreover, all Vero cells showed normal shape and growth rate during the first week compared to control cells. In addition, these materials induced antiviral effects which inhibit the cytopathic effect (CPE) of DHV (Figure 2, a and b). As shown in Table 1, the highest dilution of isolated glycyrrhizin, glycine, cysteine and mixture of glycyrrhizin, glycine and cysteine inhibited the CPE at $10^{5}$, $10^{2}, 10^{3}$ and $10^{6}$ respectively.

\section{In vivo studies \\ Clinical signs}

Ducklings of control negative group appeared normal during the experimental period. Similar signs were observed for glycyrrhizin treated ducklings. However, one vaccinated ducklings which showed signs of illness in form of depression, decreased food intake, ruffled feather and dullness at the $2^{\text {nd }}$ and $3^{\text {rd }}$ day died later. These signs started to disappear at the $4^{\text {th }}$ and $5^{\text {th }}$ day post vaccination. On the other hand, ducklings of treated and vaccinated group were slightly depressed, mildly anorexic at the $2^{\text {nd }}$ and $3^{\text {rd }}$ day post vaccination but returned to normal at the $4^{\text {th }}$ and $5^{\text {th }}$ day.

\section{Cellular immune response}

The result of lymphocyte proliferation assay (BrdU) indicated that glycyrrhizin or in conjugation with DHV live attenuated vaccine elicited a pronounced proliferation response after the $4^{\text {th }}$ day of inoculation and persisted until the end of experiment, while vaccinated group showed a pronounced proliferation response after 24 days. In contrast, the control group showed nearly negative proliferation response (Table 2)

\section{Humeral immune response (SNT)}

Antibody titers estimated weekly for 7 weeks were $(4,4,4,8,8,4$ and 32) for the treated group with mixture of glycyrrhizin, glycine and cysteine, $(8,16,64,32,32,64$ and 128$)$ for vaccinated group and $(8,16,32,32,64,128$ and 256$)$ for treated and vaccinated group. As shown in Table 3, the highest antibody titer at the $3^{\text {rd }}$ week was observed in vaccinated ducklings, while the treated and vaccinated group presented higher antibody titers from the $5^{\text {th }}$ week until the end of experiment than other groups (Table 3).

\section{Challenge test}

Challenge test at 25 days old revealed that ducklings of control group showed severe depression, ruffled feather and off food. Some ducklings were lying on their sides or breast with leg extended backward and head drown over the back with spasmodic paddling leg -movement on the $3^{\text {rd }}, 4^{\text {th }}, 5^{\text {th }}$, and $6^{\text {th }}$ day post challenge. The morbidity rate reached $80 \%$ and the mortality rate reached $70 \%$. The treated group with glycyrrhizin showed slight depression and general signs of illness at the $2^{\text {nd }}$ day post challenge, one duckling had spasmodic paddling leg-movement but returned healthy on the $3^{\text {rd }}$ day. Neither mortality nor morbidity was recorded and ducklings appeared healthy with normal size. In addition, ducklings of vaccinated group showed moderate depression and general signs of illness at the $2^{\text {nd }}$ day post challenge, one duckling died on the $3^{\text {rd }}$ day post challenge. The survived duckling was emaciated and maintained stunted growth. In contrast, high protection rate $(100 \%)$, healthy appearance, normal growth and size were observed in glycyrrhizin treated and vaccinated ducklings as shown in Table 4.

Table 1: In vitro investigation of the antiviral effect of glycyrrhizin and/or its adjuvents against duck hepatitis virus (DHV) on vero cells.

\begin{tabular}{ll}
\hline Tested material & Antiviral effect / dilution \\
\hline Isolated glycyrrhizin & + ve up to $10^{5}$ \\
Glycine & + ve up to $10^{2}$ \\
Cysteine & + ve up to $10^{3}$ \\
$\begin{array}{l}\text { Mixture (glycyrrhizin }+ \\
\text { glycine + cysteine) }\end{array}$ & + ve up to $10^{6}$ \\
\hline
\end{tabular}

Table 2: Lymphocyte proliferation assay (BrdU) (Optical density) of different experimental groups before challenge test $(\mathrm{Mean} \pm \mathrm{SD})$. 
Publisher: African Networks on Ethnomedicines

Web page: /http://journals.sfu.ca/africanem/index.php/ajtcam/indexl

http://dx.doi.org/10.4314/ajtcam.v9i3.14

\begin{tabular}{lllll}
\hline $\begin{array}{c}\text { Groups } \\
\text { Age (Days) }\end{array}$ & Control & Glycyrrhizin & Vaccinated & $\begin{array}{l}\text { Glycyrrhizin \& } \\
\text { vaccinated }\end{array}$ \\
\hline 4 & $0.153 \pm 0.020$ & $0.201 \pm 0.010^{*}$ & $0.150 \pm 0.018$ & $0.204 \pm 0.114^{*}$ \\
14 & $0.177 \pm 0.001$ & $0.232 \pm 0.010^{*}$ & $0.193 \pm 0.007$ & $0.282 \pm 0.043^{*}$ \\
24 & $0.119 \pm 0.008$ & $0.205 \pm 0.035^{*}$ & $0.303 \pm 0.004^{*}$ & $0.202 \pm 0.004^{*}$ \\
\hline
\end{tabular}

$*=p<0.05$ compared to control group.

Table 3: Serum neutralization test (SNT) of different experimental groups for estimated the antibody titers during the period of treatment before and after challenge.

\begin{tabular}{ccccc}
\hline $\begin{array}{r}\text { Groups } \\
\text { Periods (Week) }\end{array}$ & Control & Glycyrrhizin & Vaccinated & $\begin{array}{c}\text { glycyrrhizin \& } \\
\text { vaccinated }\end{array}$ \\
\hline $1^{\text {st }}$ & 0 & 4 & 8 & 8 \\
$2^{\text {nd }}$ & 0 & 4 & 16 & 16 \\
$3^{\text {rd }}$ & 0 & 4 & 64 & 32 \\
$4^{\text {th }}$ & 2 & 8 & 32 & 32 \\
$5^{\text {th }}$ & 4 & 8 & 32 & 64 \\
$6^{\text {th }}$ & $>2$ & 4 & 64 & 128 \\
$7^{\text {th }}$ & 8 & 32 & 128 & 256 \\
\hline
\end{tabular}

Table 4. Challenge test (morbidity, mortality and protection rates) by infection with duck hepatitis virus (DHV) in different experimental groups at the $25^{\text {th }}$ day old.

\begin{tabular}{|c|c|c|c|c|c|c|c|c|c|c|c|c|c|c|c|c|c|}
\hline \multirow[b]{2}{*}{ Groups } & \multirow{2}{*}{$\begin{array}{l}\text { Morbidity } \\
\text { rate }\end{array}$} & \multicolumn{14}{|c|}{ Mortality rate / days post infection } & \multirow{2}{*}{$\begin{array}{l}\text { Mortality } \\
\text { rate }\end{array}$} & \multirow[t]{2}{*}{ Protection rate } \\
\hline & & 1 & 2 & 3 & 4 & 5 & 6 & 7 & 8 & 9 & 10 & 11 & 12 & 13 & 14 & & \\
\hline Control & $80 \%$ & - & - & 2 & 3 & 1 & 1 & - & - & - & - & - & - & - & - & $70 \%$ & $30 \%$ \\
\hline Glycyrrhizin & $10 \%$ & - & - & - & - & - & - & - & - & - & - & - & - & - & - & $0 \%$ & $100 \%$ \\
\hline Vaccinated & $10 \%$ & - & - & 1 & - & - & - & - & - & - & - & - & - & - & - & $10 \%$ & $90 \%$ \\
\hline $\begin{array}{l}\text { Glycyrrhizin \& } \\
\text { Vaccinated }\end{array}$ & $0 \%$ & - & - & - & - & - & - & - & - & - & - & - & - & - & - & $0 \%$ & $100 \%$ \\
\hline
\end{tabular}

\section{Discussion}

Duck hepatitis virus is one of economic important diseases to all duck growing farms because of its high potential mortality if the infection is not controlled. The present work was conducted to investigate the effect of GL as antiviral and immune stimulant against DHV. It is based on immunological responses. In the present study, the result of purification and identification of GL from licorice root revealed that GL had the same band of standard GL on the silica gel at retention factor (RF) 0.76 of standard and 0.74 of isolated GL. Similar result was reported by Cui et al. (2005).

In vitro study of the cytotoxicity assay of GL on Vero cells revealed that GL had no toxic effect. GL inhibited the cytopathic effect (CPE) of DHV on Vero cells up to the dilution of $10^{6}$. Baltina (2003) recorded that the $\mathrm{LD}_{50}$ of purified GL $(95 \%)$ was $5000 \mathrm{mg} / \mathrm{kg} /$ day/orally in mice. Inhibition of DHV cytopathic effect could be the result of GL antiviral effect. GL affects the cellular signaling pathway such as protein kinase c; case in kinase 11 and transcription factors such as activator protein 1 and nuclear factor. GL and its aglycone metabolite glycrrhetinic acid regulate expression of inducible nitrous oxide synthase and production of nitrous oxide in macrophage (Crance et al. 2003). The antiviral activity of GL is mediated by an interaction with the cell membrane which most likely results in reduced endocytotic activity and hence reduced virus uptake (Wolkerstorfer et al., 2009).

Lymphocyte proliferation assay indicated that GL alone or in conjugation with duck hepatitis vaccine elicited a pronounced proliferation response in contrast to the control group. This was explained by Shinada et al. (1986) who reported that RNA and protein synthesis of the treated lymphocyte with glycyrrhizin increased compared to control cells; DNA synthesis, however, was reduced. Collaboration between enriched T-lymphocytes and macrophages, both treated with glycyrrhizin was needed for the enhancement of interferon-gamma production. GL has been shown to stimulate endogenous interferon production in addition to its antioxidant and detoxifying effects (Saves et al., 2000). A slight increase in interferon production was also observed in the glycyrrhizin-treated peripheral lymphocyte-macrophage cultures derived from an asymptomatic carrier of hepatitis B virus. Finally the GL-mediated the bidirectional controls of the lymphocyte growth response. The bidirectional controls demonstrated may be significant in normalizing the lymphocyte responses to very weak 
Publisher: African Networks on Ethnomedicines

Web page: /http://journals.sfu.ca/africanem/index.php/ajtcam/indexl http://dx.doi.org/10.4314/ajtcam.v9i3.14

or very high stimuli (Zhang et al., 1992) or may be due to the action of GL to stimulate macrophage to release interleukin-1 which is mainly concerned with activation of lymphocytes.

Antibody titers against DHV estimated by SNT were higher in vaccinated and vaccinated-treated birds with GL. These results expressed the elevation of immune response as stated by Abd-Elwanis (1999). The high antibody titer in

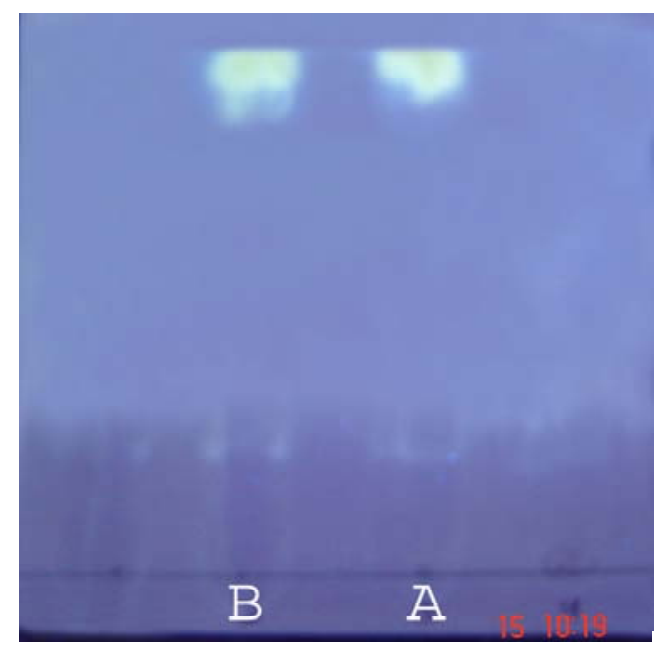

Figure 1: Purification and identification of glycyrrhizin from licorice by thin layer chromatography
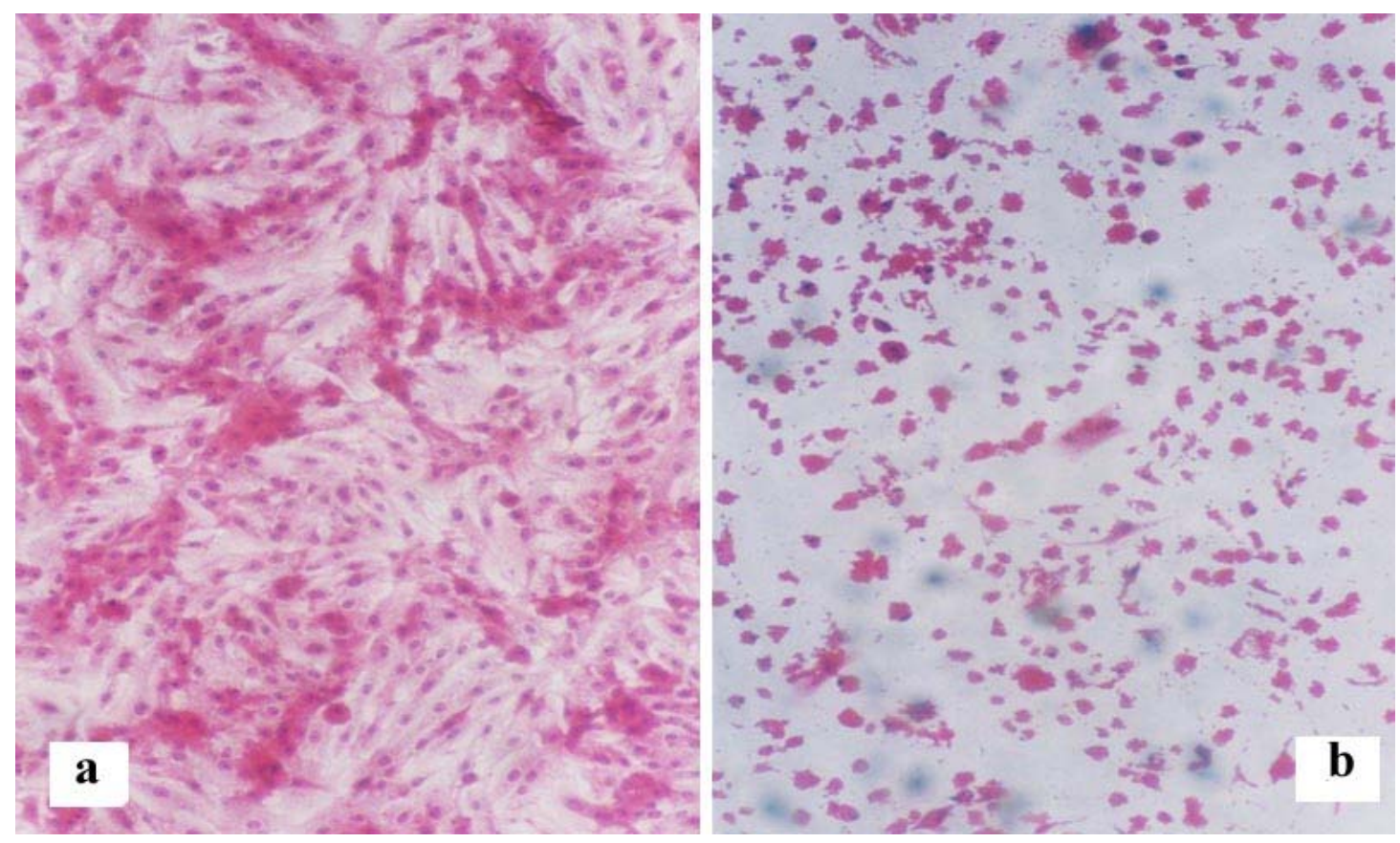

Figure 2: (a) Vero cell showing normal shape in both control and inoculated groups with glycyrrhizin, glycine, cystien, and Mixture of (glycyrrhizin + glycine+cystien). (b) The cytopathic effect caused by duck hepatitis virus (DHV) in Vero cells.

vaccinated group is related to the effectiveness of the local live attenuated vaccine (El-Koffy et al. 1999). The lowest antibody titer in treated unvaccinated group is related to the non-specific immune response of GL. The very high titer in treated-vaccinated group could be attributed to the action of GL inducing interleukin-12 by peritoneal macrophages. The priming effect of GL on interleukin-12 production was independent of both gamma interferon and granulocyte macrophagecolony-stimulating factor (GM-CSF) production (Dai et al., 2001; Wolkerstorfer, et al., 2009). Also, GL acts as a promoter of the late signal transduction of T lymphocytes for IL-2 production (Zhang et al., 1993).

Challenge test at the $25^{\text {th }}$ day old revealed that the mortality rate was highest in the control group infected with DHV only as $70 \%$ of ducklings died at the $3^{\text {rd }}, 4^{\text {th }}, 5^{\text {th }}$ and $6^{\text {th }}$ day post inoculation. The high mortality rate could be attributed 
Publisher: African Networks on Ethnomedicines

Web page: /http://journals.sfu.ca/africanem/index.php/ajtcam/indexl http://dx.doi.org/10.4314/ajtcam.v9i3.14

to the deteriorated effect of the virus on the liver and kidneys as well as its immunosuppressive effect. This mortality was confirmed by the recorded liver gross lesions in the form of hemorrhagic streaks. Similar results were reported by Saif et al. (2003) and Mahdy (2005). Vaccinated group showed $10 \%$ mortality after challenge with virus. The $90 \%$ protection confirm the protective effect of the vaccine, while the treated group with GL showed no mortality which may be due to the enterohepatic cycle of GL, antiviral, immune stimulant, anti-inflammatory and antioxidant effect (Michael-Avirum, 2004; Houssen et al, 2010; Shi, et al., 2010). Glycyrrhizin treated and vaccinated group showed no mortality or morbidity reflecting both the efficiency and potency of GL and DH vaccine in controlling the virus (Maatooq, et al., 2010).

\section{Conclusion}

The treatment with glycyrrhizin alone or in combination with duck hepatitis vaccine expressed a good immune stimulant and antiviral effect against Duck hepatitis virus infections.

\section{References}

1. Abd El-Wanis, N.A. (1999). Preparation and elevation of hyperimmune serum against ND virus in different hosts. Egyptian Vet. Med. Assoc. 59: 1029-1039.

2. Baltina, L.A. (2003). Chemical modification of glycyrrhizic acid as a route to new bioactive compounds for medicine. Curr. Med. Chem. 10: 155-171.

3. Bentley, R. and Trimen, H. (1880). Medicinal Plants. Extractum glycyrrhiza (U.S.P). Extract of Glycyrrhiza. Medicinal Plants, 74. Published by J. \& A. Churchill in London.

4. $\quad$ Chung, W., Lee, S.H., Kim, J., Sung, N., Hwang, B., Lee, S.Y., Yu, C., Lee, H. (2001). Effect of the extracts from Glycyrrhiza uralensis Fisch on the growth characteristics of human cell lines: antitumor and immune activation activities. Cytotechnol. 37: 55-64.

5. Cinatl, J., Vogel, U., Cinatl, J., Kabickova, H., kornhuber, B. and Doerr, H.W. (1997). Antiviral effects of 6-diazo5-oxo-L norleucin on replication of herpes simplex virus type-1. Antiviral Res. 33: 165-175.

6. Crance, J.M., Scaramozzino, N., jouan, A., Garin, D. (2003). Interferon, ribavirin, 6-azarridine and glycyrrhizin: antiviral compounds active against pathogenic flavi viruses. Antiviral Res. 58: 73-79.

7. Cui, S.H., Fu, B., Lee, F.S. and Wang, X. (2005). Application of microemulsion thin layer chromatography for the finger printing of licorice. J. Chromatography B 828: 33-40.

$8 . \quad$ Dai, J. Hong, I. Y., Ishida, T., Terunuma, H., Kasai, H., Iwakula, Y., Fujiwara, H., Ito,M. and Dai, J.H. (2001). Glycyrrhizin enhances interleukin-12 production in peritoneal macrophages. Immunol. 103: 235-243.

9. $\quad$ El-Koffy, Mervat, A., Khodeir, M.H., Abd El-Khaleck, M.A. and Abou-El Khair, M.A. (1999). Preparation of a combined inactivated vaccine against DVH and Duck virus enteritis (Duck plague). Alexandria J. Vet. Sci. 15: 627-637.

10. Florence, G.; Burleson, T.; Chambers, M. and Danny, L. W. (1992). Virology: A Laboratory Manual. Academic Press, New York.

11. Hattori M, Sakamoto T, Kobashi K, Namba T. (1983). Metabolism of glycyrrhizin by human intestinal flora. Planta Medica 48:38-42

12. Houssen, Maha E., Ragab, Amany, Mesbah, Abeer, El-Samanoudy, A.Z., Othman, G., Moustafa, Amal F., Badria, F.A. (2010). Natural anti-inflammatory products and leukotriene inhibitors as complementary therapy for bronchial asthma. Clin. Biochem. 43: 887-890.

13. Hu, J.M. and Hsiung, G.D. (1989). Evaluation of new antiviral agents I: in vitro perspectives. Antiviral Res. 11: 217-232.

14. Khodier, M.H. and Sahar. A.S. (2006). Antioxidant and antiviral activities of some traditionally used herbs and spices in Egypt. Arabian J. Biotechnol. 9: 231-240.

15. Maatooq, G.T., Marzouk, Amani, M, Gray, A.I., Rosazza, J.P. (2010). Bioctive microbial metabolites from glycyrrhetinic acid. Phytochem. 71, 262-270.

16. Mahdy, Salwa, A. (2005). Clinicopathological studies on the effect of duck viral hepatitis in ducks. M.V.Sc Thesis (Clinical Pathology), Faculty of Veterinary Medicine, Zagazig University.

17. Mao, S.J., Hou, S.X., He, R., Zhang, L.K., Wei, D.P., Bi, U.Q. and Jin, H. (2005). Uptake of albumin nanoparticle surface modified with glycyrrhizin by primary cultured rat hepatocytes. World J. Gastroenterol. 11: 3075-3079

18. Michael-Aviram (2004). Flavonoids rich nutrients with potent antioxidant activity prevent atherosclerosis development, the licorice example. Int. Congress series volume 1262 May, 320-327.

19. Mori, K., Sakai, H., Suzuki, S., Akutsu, Y., Ishikawa, M., Imaizumi, M., Tada, K., Aihara, M., Sawada, Y., Yokoyama, M., Sado, Y., Endo, Y., Suzuki, Z., Sato, S., Sasaki, H., Yokohama, S., Hayshi., T., Uchida, T., Hiwatashi, K., Ishida, N., Fujimaki, M. and Yamada, K. (1990). Effects of glycyrrhizin (SNMC: Stronger Neo-Minophagen C) in hemophilia patients with HIV-1 infection. Tohoku J. Exp. Med. 162:183-193

20. Nagai, T., Egashira, T., Kudo, Y., Yamanaka, Y., Shimada, T. (1992). Attenuation of dysfunction in the ischemiareperfused liver by glycyrrhizin. Japanese J. Pharmacol. 58: 209-218.

21. NRC (National Research Council) (1994). Nutrient Requirements of Poultry. $9^{\text {th }}$ revised edition, National Academy Press, Washington, D.C.

22. Perros, P. and Weightman, D.R. (1991). Measurement of cell proliferation by enzyme- Linked immunosorbent assay (ELISA) using a monoclonal antibody to bromodeoxy uridine. Cell Proliferation 24: 517-523. 
Publisher: African Networks on Ethnomedicines

Web page: /http://journals.sfu.ca/africanem/index.php/ajtcam/indexl http://dx.doi.org/10.4314/ajtcam.v9i3.14

23. Reed, L.J. and Muench, C. (1938). A simple method of estimating fifty percent end points." American J. Hyg. 27: 493-497.

24. Saif, Y.M., Barnes, H.J., Glissons, J.R., Fadly A.M., McDougald L.R and Swayne D.E. (2003). Diseases of Poultry. $11^{\text {th }}$ Ed. Lowa State Press, A Blackwell Publishing Company.

25. Saves, M., Raffi F, Clevenbergh P, and Manchou B. (2000). Hepatitis B or hepatitis C virus infection is a risk factor for severe hepatic cytolysis after initiation of a protease inhibitor-containing antiretroviral regimen in human immunodeficiency virus-infected patients. Antimicrob. Agents and Chemother. 44: 3451-3455.

26. Shi, J.R., Mao, L.G., Jiang, R.A., Qian, Y., Tang, H.F. and Chen, J.Q. (2010). Monoammonium glycyrrhizinate inhibited the inflammation of LPS-induced acute lung injury in mice. Int. Immunopharmacol. 10(10): 1235-1241.

27. Shinada, M., Azuma, M., Kawai, H., Sazaki, K., Yoshida, I., Yoshida, T., Suzutani, T. and Sakuma, T. (1986). Enhancement of interferon gamma production in glycyrrhizin treated human peripheral lymphocytes in response to concanavalin A and to surface antigen of hepatitis B virus. Proceedings of the Society for Exp. Biol. Med. 181: 205-210.

28. Singh, K.V., Osman, O.A., Thanaa, I. Baz and Ivon, El-Cicy, (1967). Colostral transfer rinderpest neutralizing antibodies to offspring of vaccinated dams. Canadian Journal Comparative Medicine Veterinary Science 31, $295-298$.

29. Snedecor, G.W. and Cochran, W.G. (1982): Statistical Methods. $8^{\text {th }}$ Ed. Iowa State University Press, U.S.A.

30. Wolkerstorfer, A., Kurz, H., Bachhofner, N. and Szolar, O.H.J. (2009). Glycyrrhizin inhibits influenza A virus uptake into the cell. Antiviral Res. 83: 171-178.

31. Yang, B.S., Ma, Y.J., Wang, Y., Chen, L.Y., Bi, M.R., Yan, B.Z., Bai, L., Zhou, H., Wang, F.X. (2007). Protective effect and mechanism of stronger neo-minophagen C against fulminant hepatic failure. World J. Gastroenterol. 13: $462-466$.

32. Zhang, Q.Y. and Ye, M. (2009). Chemical analysis of the Chinese herbal medicine Gan-Cao (licorice). J. Chromatography A 1216: 1954-1969.

33. Zhang, Y.H., Isobe, K., Iwamoto, T. and Nakashima, I. (1992). Bi directional control by glycyrrhizin of the growth response of lymphocytes stimulated through a receptor by passed pathway. Immunol. Lett. 32: 147-152.

34. Zhang, Y.H., Isobe, K., Nagase, F., Lwin, T., Kato, M., Hamaguchi, M., Yokochi, T. and Nakashima, I. (1993). Glycyrrhizin as a promoter of late signal transduction for interleukin-2 production by splenic lymphocyte. Immunol. 79: 528534. 